\title{
Uterine Corpus Cancer pT1a TNM Finding v6
}

National Cancer Institute

\section{Source}

National Cancer Institute. Uterine Corpus Cancer pT 1a TNM Finding v6. NCI Thesaurus. Code C61343.

Uterine corpus cancer with tumor limited to the endometrium. (from AJCC 6th Ed.) 